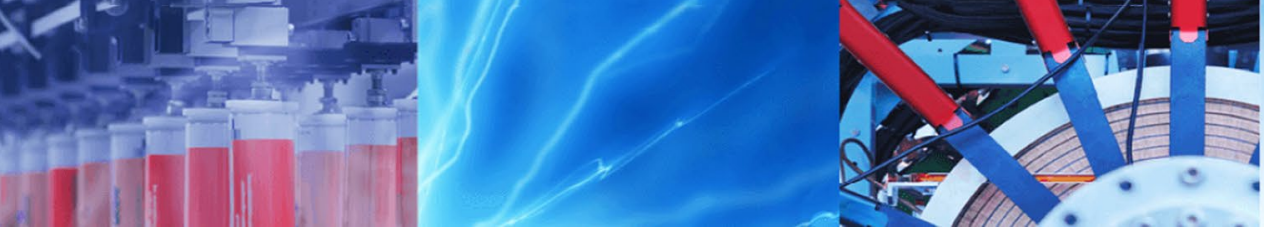

Research Article

\title{
Monitoring of drinking water from the karst springs of the Ljuberadja-Niš water supply system (Serbia)
}

\author{
Slavica D. Stevanovićc ${ }^{10}$ - Jovana N. Krstić ${ }^{2}$ Branka T. Stojanović ${ }^{2} \cdot$ Dušan Đ. Paunović ${ }^{2}$ Danica S. Dimitrijević ${ }^{2}$. \\ Jasmina M. Veličković ${ }^{2} \cdot$ Novica J. Stanković ${ }^{2}$
}

Received: 28 March 2020 / Accepted: 13 October 2020 / Published online: 20 October 2020

(c) Springer Nature Switzerland AG 2020

\begin{abstract}
The Ljuberadja-Niš water supply system is one of the main components of the Niš water supply system. This system consists of a series of natural, karst springs of groundwater (Krupac, Mokra, Divljana, Ljuberadja), with the capacity of 800-1450 L/s. The most important factors in a healthy drinking water supply are the proper choice and protection of water springs. Considering that water composition may sometimes have an adverse effect on consumer health, production processes in some industries and also on facilities and water company equipment, the aim of this paper was to examine water composition and to monitor its quality by analyzing the physical, chemical, and microbiological indicators. Water quality is tested in accordance with the corresponding directives and regulations of national and international authorities. The analysis of drinking water encompassed the appointment of the following parameters (quality indicators): physical parameters: temperature, turbidity, $\mathrm{pH}$ value and electrical conductivity of water; chemical parameters: chloride, ammonia, nitrite, nitrate, sulfate, calcium, magnesium, iron, manganese, aluminum and chromium in the form of $\mathrm{Cr}^{6+}$ and $\mathrm{Cr}^{3+}$ ions; microbiological parameters: culturable organisms, total and fecal coliform bacteria, intestinal enterococci, sulfite reducing clostridia, Pseudomonas aeruginosa and Proteus strain. Monitoring has confirmed the hygienic and health adequacy of the water distributed to cosumers.
\end{abstract}

Keywords Drinking water $\cdot$ Monitoring $\cdot$ Quality indicators

\section{Introduction}

The most important factors in a healthy drinking water supply are the proper choice and protection of water springs [39]. Groundwater is the most reliable source of drinking water because of the minimized anthropogenic influence like the widespread use of chemical fertilizers and rapid urbanization of populated areas extending beyond the protected sanitary catchment zones [3].

In northern Europe, groundwater exploitation has substantially increased in the past two centuries. Nowadays, a significant part of western and central Europe obtains drinking water from groundwater springs. For citizens of Italy, Iceland, Austria, Denmark, and Lithuania groundwater accounts for nearly $90 \%$ of the total water consumption. With the citizens of France, Sweden, and Finland that percentage is around $50 \%$ and it is similar in Germany and the Netherlands (50-79\%). In England, 30-35\% of drinking water is groundwater, whereas in Norway, the percentage is the lowest-about 15\% [25]. It is estimated that groundwater satisfies about $70 \%$ of the water demand in Serbia [4].

Natural phenomena may affect water quality at spring sites:

Slavica D. Stevanović, slavlab@gmail.com | 'Sanitary Medical School of Applied Sciences "VISAN“, 7a Tošin bunar, 11000 Belgrade, Serbia. ${ }^{2}$ Department of Applied Ecology, Faculty of Applied Sciences, University of 'Union-Nikola Tesla' Belgrade, 22a Dušana Popovića, 18000 Niš, Serbia. 
- Air, water and ground and precipitation temperature changes;

- Drainage via the surface of the ground, dipping, physical, chemical, biological and biochemical changes of water composition on the surface and in the ground;

- Contamination by organisms in nature.

Fecal contamination of water springs is still a global issue, particularly in countries with low and medium income. The latest study performed in Indonesia estimates that the greatest risks of intestinal infections appear as a result of fecal contamination in spring and well water [14]. Agricultural activities such as the application of manure to arable land and grazing cattle in pastures offer economic and ecological advantages, but on the other hand, they pose a risk of microbiological contamination in water springs [32]. Escherichia coli (E. coli), which is an indicator of fecal contamination, is part of the microbiological flora of human and animal feces, and it can be found in wastewaters, all natural waters and in the ground. E. coli and intestinal enterococci are marked by the World Health Organization as the general indicators of fecal contamination of water [42, 45].

The Ljuberadja-Niš water supply system is one of the main components of the Niš water supply system. It supplies about 250,000 residents of the city of Niš and the local economy. This system consists of a series of natural, karst springs of groundwater (Krupac, Mokra, Divljana, Ljuberadja), with the capacity of 800-1450 L/s.

Ljuberadja Spring is a sprawling karst spring consisting of a series of separate springs in the valley of the Lužnica upstream from the village of Ljuberadja at a length of $500 \mathrm{~m}$. Between 1981 and 1984, five springs were tapped and incorporated into the water supply system of Niš. Good-quality groundwater flows out of karstified

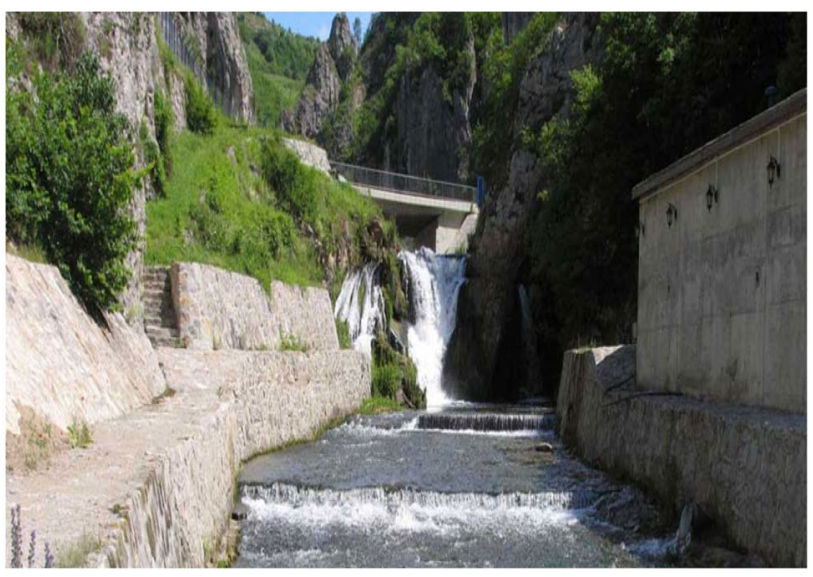

Fig. 1 Ljuberadja Spring limestone from the Lower Cretaceous with the capacity ranging between 450 and $5500 \mathrm{~L} / \mathrm{s}$ (Fig. 1).

Divljana Spring is located on the left bank of the Koritnica, opposite the village of Divljana in close proximity to the Bela Palanka-Babušnica road. It has been in the city's water supply system since 1984 . The main reservoirs of groundwater are carbonate deposits (limestone) from the Lower Cretaceous with the flow capacity ranging from the minimum 45-60 L/s to the maximum 1500 L/s (Fig. 2).

Mokra Spring in the vicinity of the village of Mokra and at the foot of Suva Planina is essentially the source of the Mokranjska river, which is the left tributary to the Koritnica. It has been in the city's water supply since 1984 . From a lithological perspective, almost the entire drainage basin of the spring is built of carbonate rocks-limestone and dolomite from the Lower Cretaceous. The average perennial yield is $310 \mathrm{~L} / \mathrm{s}$ (Fig. 3).

Krupac Spring penetrates the rocky mass at the village of Krupac where the sides of the mountains around

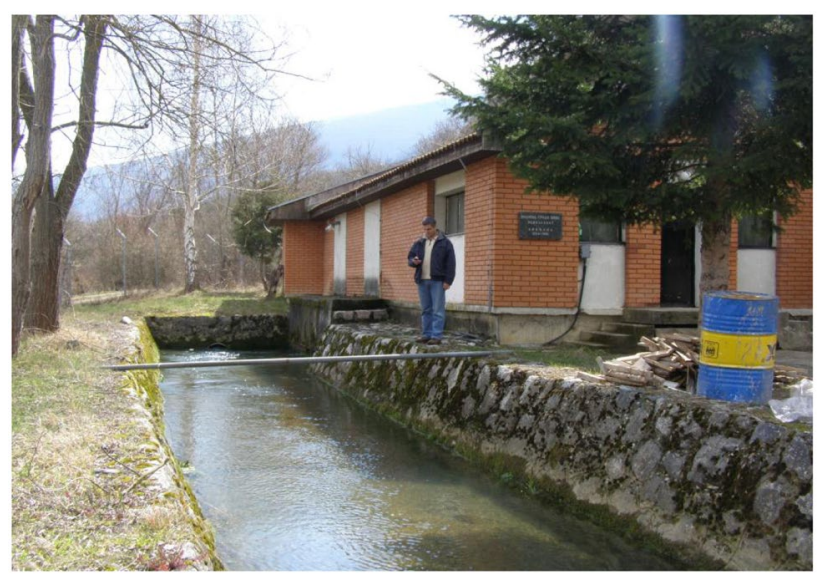

Fig. 2 Divljana Spring

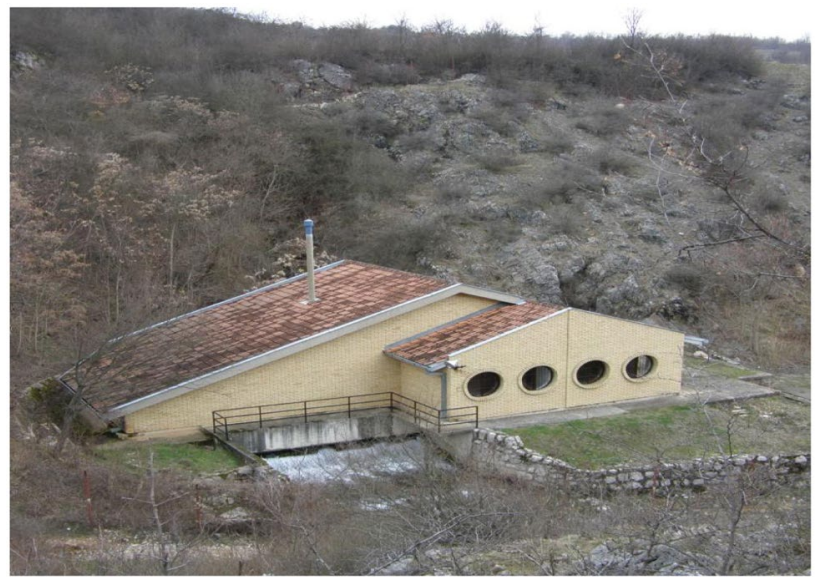

Fig. 3 Mokra Spring

\section{SN Applied Sciences}


Svrljig steeply descend into the basin of Bela Palanka. Between 1981 and 1984, the spring was tapped and introduced into the water supply system of Niš. It is a common karst spring and Cretaceous limestone predominates in its collecting area. It is categorized as the highest yield spring but simultaneously one of its characteristics is large yield fluctuations ranging from the minimum of $35 \mathrm{~L} / \mathrm{s}$ to the maximum of $10,000 \mathrm{~L} / \mathrm{s}$ (Fig. 4).

The area has a moderate continental climate with prevailing mountainous climate, with average annual precipitation of $602 \mathrm{~mm}$ and the average annual air temperature of $11.3^{\circ} \mathrm{C}$ (Fig. 5).

After chlorination (with gas chlorine) the water from these springs is directed to the Vinik reservoir and is thereafter distributed to consumers.

Water analysis is conducted with adherence to set rules pertaining to sampling and it involves ascertaining the physical, chemical and microbiological indicators of water quality.

Considering that water composition may sometimes have an adverse effect on consumer health, production processes in some industries and also on facilities and water company equipment, the aim of this paper was to examine water composition and to monitor its quality by analyzing the physical, chemical and microbiological indicators.

Bacteria concentrations may be used for mathematical modeling with the view of predicting bacteriological contamination of natural water [19]. However, modeling cannot anticipate low concentrations of fecal contamination whereby water quality monitoring remains a priority in assessing intestinal infection health risks and waterborne disease risks [36].

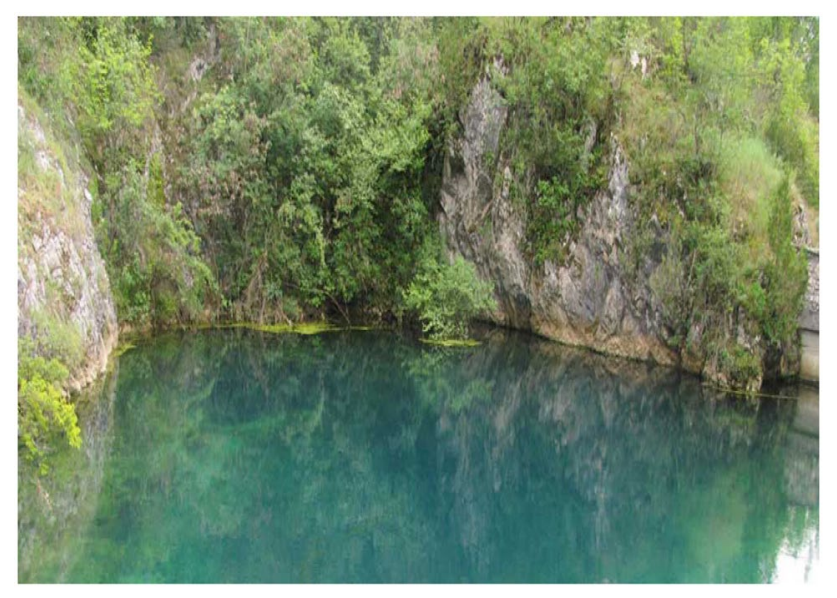

Fig. 4 Krupac Spring

\section{Materials and methods}

\subsection{Water quality monitoring}

Water quality is tested in accordance with the corresponding directives and regulations of national and international authorities. In the Republic of Serbia, drinking water quality is determined by the Ordinance on the hygienic adequacy of drinking water in the Republic of Serbia [35] which is aligned with the Europian Union Council Directive 98/83/EC [7], US EPA, Edition of the Drinking Water Standards and Health Advisories, EPA 822-S-12-001 [38] and the WHO, Guidelines for Drinkingwater Quality [44]. Drinking water quality is regulated by the stipulation of maximum permitted levels of certain parameters.

Physicochemical and microbiological drinking water quality monitoring is accomplished by performing basic and periodic sample examinations of natural spring water (before disinfection with gas chlorine) and chlorinated water from the Vinik reservoir (after disinfection with gas chlorine and before discharge into the distribution system).

Sample testing was performed in an accredited laboratory, JKP "Naissus" Niš (SRPS ISO/IEC 17025: 2006). Water samples for physicochemical and microbiological examinations were taken by experts in accordance with the standards: SRPS EN ISO 5667-1:2008, SRPS EN ISO 5667-3:2017, SRPS EN ISO 5667-5:2008 and SRPS EN ISO 19458:2009.

\subsection{Quality indicators (parameters) and methods}

The analysis of drinking water encompassed the appointment of the following parameters:

Physical parameters (methods): temperature (SRPSH. Z1.106:1970), turbidity (EN ISO 7027: 1999), pH (EN ISO 10523:2008) value and electrical conductivity (SRPS EN 27888:2009) of water.

Chemical parameters (methods): chloride (SRPS ISO 9297/1:2007 revision 1), ammonia (SRPS.H.Z1.184:1974), nitrite (SRPS ISO 26777:2009), nitrate (spectrophotometric-Manual P-V-31/C (Standard methods for testing hygienic correctness "Drinking water" [33])), sulfate (USEPA 375.4:1978), calcium and magnesium (USEPA 215.2:1978-Ca, Mg- by calculation from calcium), iron (SRPS ISO 6332:2003), manganese (spectrophotometricManual P-V-26A (Standard methods for testing hygienic correctness "Drinking water" [33])), aluminum (ISO 10566:1994) and chromium in the form of $\mathrm{Cr}^{6+}$ and $\mathrm{Cr}^{3+}$ ions (ISO 11083:1994(E)). 
$\mathrm{N}$

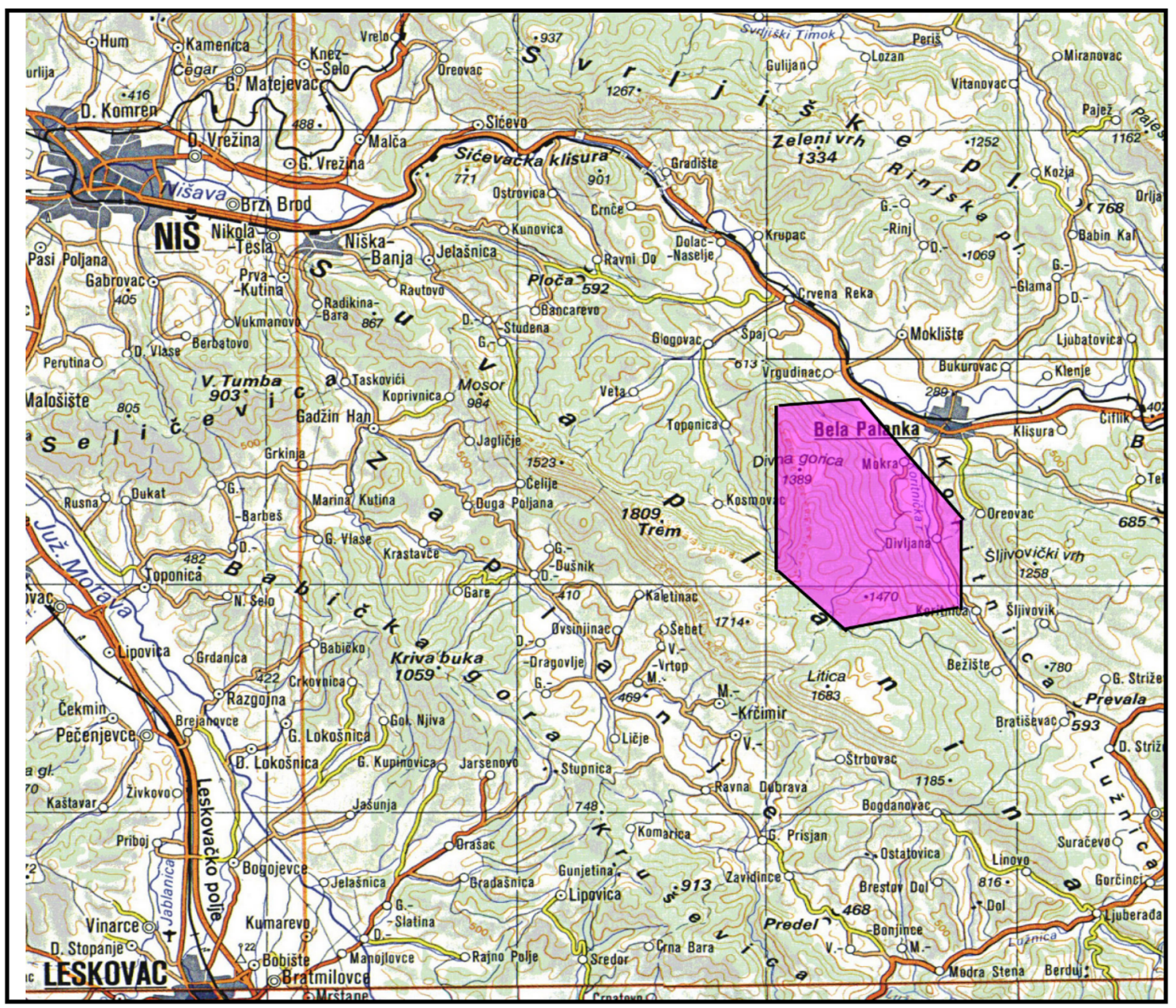

scale 1: 25000

$\mathrm{S}$

Legend:

Research area (about $52 \mathrm{~km}^{2}$ )

Fig. 5 Map of the research area

Microbiological parameters (methods): culturable organisms (SRPS EN ISO 6222: 2010); total and fecal coliform bacteria (SRPS EN ISO 9308-1:2010); Intestinal enterococci (SRPS EN ISO 7899-2:2010); sulfite reducing clostridia, Pseudomonas aeruginosa and Proteus strain (methods in the Manual (Standard methods for testing hygienic correctness "Drinking water" [33])).

The water from the water system Ljuberadja-Niš was examined in the period between January 2018 and December 2018 with the sampling frequency of once a month for determining the physical parameters of water, chloride, ammonia, nitrite, nitrate, $\mathrm{Fe}, \mathrm{Mn}$ and microbiological parameters. The sampling frequency for $\mathrm{Cr}^{6+}, \mathrm{Cr}^{3+}$ and Al was four times a year.

\section{Results and discussion}

\subsection{Physical-chemical water quality monitoring}

Physical parameters are important indicators of water quality. Temperature measurements, turbidity, $\mathrm{pH}$ value 
and electrical conductivity results for the springs Divljana, Mokra, Krupac, Ljuberadja, and the Vinik reservoir are presented in Table 1.

Water temperature is not standardized by national and international standards because it does not affect health directly, but it does influence the chemical and microbiological processes in water. In the northern parts of Serbia (where, according to the official data, is the worst water quality in Serbia), in Bačka, the groundwater temperature ranges from 14 to $24^{\circ} \mathrm{C}$ [23], while in the Ljuberadja-Niš system water is colder $\left(7.9-18.4^{\circ} \mathrm{C}\right)$.

The chloride concentration in all water samples from the springs and the reservoir is below the method's detection threshold $(<5.0 \mathrm{mg} / \mathrm{L})$, and they meet the recommended value and the maximum allowed content. In natural waters, chloride appears in low concentrations, but chloride content increases with mineral content growth. High chloride concentrations raises the electrical conductivity and increase the tendency of water to cause corrosion in distribution systems [34]. Chlorides of themselves are not toxic to humans. For this reason, WHO [44] did not issue chloride directives. According to US EPA [38], chloride concentration in drinking water poses no risk to human health which is why a secondary maximum contaminant level (MCL) of $250 \mathrm{mg} / \mathrm{L}$ was issued (same as the Ordinance on the hygienic adequacy of drinking water in the Republic of Serbia [35]). At higher concentrations, chlorides give water a salty taste. According to the EU Directive [7], the maximum allowed content for chlorides is $200 \mathrm{mg} / \mathrm{L}$. In Serbia, Banat, groundwater has low chloride content ranging from 5 to $50 \mathrm{mg} / \mathrm{L}$ [22].

The ammonium-nitrogen concentration $\left(\mathrm{NH}_{4}{ }^{+}-\mathrm{N}\right)$ in all water samples from the springs and the reservoir is below the method's detection threshold ( $<0.04 \mathrm{mg} \mathrm{NH}_{4}{ }^{+}-\mathrm{N} / \mathrm{L}$ ) and they meet the recommended value and the maximum allowed content. The natural level of ammonia in groundwater is generally lower than $0.2 \mathrm{mg} / \mathrm{L}$. High concentrations may be expected in layers rich in humic acid or iron. The presence of ammonia in concentrations higher than the geological level is an important factor for fecal contamination. Research indicates that monitoring low levels of free ammonia in chloraminated water is important for effectively managing potable water disinfection [12]. Ammonia is not of direct relevance to human health in concentrations expected in drinking water so WHO [44] and US EPA [38] did not set guidelines for this parameter. According the Ordinance on the hygienic adequacy of drinking water in the Republic of Serbia [35], the maximum allowed concentration for ammonium ion is $0.5 \mathrm{mg} / \mathrm{L}$. In Serbia, southern Banat, groundwater has low ammonium ion content from 0.72 to $2.75 \mathrm{mg} / \mathrm{L}$ [22].

Nitrates and nitrites may occur in water naturally, but anthropogenic processes are the most common causes: excessive use of inorganic nitrogen fertilizers, wastewater, cesspools, runoff from farms, industrial wastewater, etc. Nitrite is an unstable nitrogen form and bacteria relatively quickly convert it into nitrate which is why nitrite concentration in an ecological environment such as water is very low even when nitrate concentration is high. Nitrate concentrations at the exit of the waterworks are highly correlated with nitrate concentrations within the distribution net or at the consumers' taps, while nitrite and ammonium concentrations are generally lower within the net compared with the exit of the waterworks due to nitrification [30]. According to WHO [44], the border limit for nitrates in drinking water is $50 \mathrm{mg} / \mathrm{L}$ (or $11 \mathrm{mg} \mathrm{NO}^{3-}-\mathrm{N} / \mathrm{L}$ ). It is based on the epidemiological evidence of methemoglobinemia in children appearing after brief exposure. The limit for nitrite is $3 \mathrm{mg} / \mathrm{L}$ (or $0.9 \mathrm{mg} \mathrm{NO}^{2-}-\mathrm{N} / \mathrm{L}$ ). Due to the possibility of a simultaneous nitrite and nitrate presence in water, the sum of the concentration ratio of each component and its limit value cannot exceed 1. US EPA [38] set the maximum allowed concentration for nitrates (measured as $\mathrm{N}$ ) and nitrites (measured as $\mathrm{N}$ ) of $10 \mathrm{mgNO}^{3-}-\mathrm{N} / \mathrm{L}$ and $1 \mathrm{mgNO}^{2-}-\mathrm{N} / \mathrm{L}$, respectively. An infant under six months consuming water with nitrates and nitrites in concentrations higher than the maximum contamination level may get sick or even die. Symptoms include shortness of breath and blue baby syndrome. According to the EU Directive [7] the upper limit for nitrate and nitrite presence in drinking water is $50.0 \mathrm{mg} / \mathrm{L}$ and $0.5 \mathrm{mg} / \mathrm{L}$ respectively, under the condition that $\{[$ nitrates $] / 50+[$ nitrites $] / 3\} \leq 1$. According to the Ordinance on the hygienic adequacy of drinking water in the Republic of Serbia [35] the maximum allowed concentration for nitrates is $50.0 \mathrm{mg} / \mathrm{L}$ and $0.03 \mathrm{mg} / \mathrm{L}$ for nitrites. The nitrate-nitrogen concentration $\mathrm{NO}^{3-}-\mathrm{N} / \mathrm{L}$ in all water samples from the springs and the reservoir with the highest measured value of $3.9 \mathrm{mg} / \mathrm{L}$ are far below the recommended values and the maximum allowed content. (Table 1). The nitric nitrogen concentration $\left(\mathrm{NO}^{2-}-\mathrm{N}\right)$ in all water samples from the springs and the reservoir are below the method's detection threshold $(0.005$ $\mathrm{mgNO}^{2-}-\mathrm{N} / \mathrm{L}$ ) and therefore meet the recommended values and the maximum allowed content. In the USA, Texas, a region that aside from oil and natural gas production also engages in agriculture, the groundwater nitrate concentration varies from $<0.44$ to $149 \mathrm{mg} / \mathrm{L}$ whereby in 3 out of 40 water samples nitrate concentration exceeds the national standard of $44 \mathrm{mg} / \mathrm{L}$ [13]. Statistics show that nitrate concentration drops with well depth [13].

The greatest sulfate concentration was measured in the Vinik reservoir $16.8 \mathrm{mg} / \mathrm{L}$ in March whereas the lowest concentration was measured at Divljana Spring $6.20 \mathrm{mg} / \mathrm{L}$ in September (Table1). Sulfates are the least toxic anions. Available literature does not indicate a sulfate concentration in water that may be detrimental to health. 
Table 1 An annual basis representation of temperature, color, turbidity, $\mathrm{pH}$ value, electrical conductivity, nitrate, $\mathrm{Ca}$, Mg and sulfate of raw water from the springs Divljana (D), Mokra (M), Krupac (K) and Ljuberadja (Lj), and chlorinated water from the Vinik (V) rezervoir

\begin{tabular}{|c|c|c|c|c|c|c|c|c|c|c|c|c|}
\hline Month & January & February & March & April & May & June & July & August & September & October & November & December \\
\hline \multicolumn{13}{|c|}{ Temperature $\left({ }^{\circ} \mathrm{C}\right)$} \\
\hline $\mathrm{D}$ & 11.9 & 12.9 & 11.4 & 11.3 & 10.7 & 13.0 & 13.4 & 14.5 & 14.4 & 14.8 & 12.2 & 10.4 \\
\hline M & 14.0 & 17.1 & 11.4 & 13.4 & 11.6 & 12.6 & 18.0 & 14.8 & 15.3 & 18.4 & 17.3 & 14.0 \\
\hline $\mathrm{K}$ & 12.1 & 11.4 & 10.9 & 10.7 & 10.9 & 12.9 & 13.1 & 14.8 & 14.8 & 11.3 & 11.3 & 7.9 \\
\hline $\mathrm{Lj}$ & 8.7 & 13.0 & 10.4 & 11.1 & 11.1 & 13.9 & 12.1 & 14.4 & 14.1 & 13.2 & 10.6 & 8.3 \\
\hline V & 11.4 & 11.0 & 11.0 & 11.7 & 11.2 & 12.4 & 13.9 & 16.7 & 16.1 & 13.9 & 14.4 & 11.7 \\
\hline \multicolumn{13}{|c|}{ Turbidity (NTU) } \\
\hline $\mathrm{D}$ & $<0.20$ & $<0.20$ & 0.30 & 0.36 & 0.21 & 0.67 & 0.38 & 0.25 & 0.80 & $<0.20$ & 0.28 & 1.30 \\
\hline M & $<0.20$ & 0.25 & 0.33 & 0.33 & 0.33 & 0.60 & 0.30 & 0.25 & 0.20 & 0.24 & 0.25 & 1.55 \\
\hline $\mathrm{K}$ & 0.48 & 5.70 & 0.37 & 0.30 & 0.22 & 0.36 & 0.74 & 0.29 & 0.60 & 0.22 & 0.31 & 5.40 \\
\hline $\mathrm{Lj}$ & 0.81 & 0.60 & 0.52 & 0.54 & 0.71 & 0.67 & 0.48 & 0.45 & 0.57 & 0.24 & 0.60 & 1.70 \\
\hline V & 0.29 & 0.28 & 0.34 & 0.24 & 0.2 & 0.4 & 0.55 & 0.48 & 0.37 & 0.3 & 0.24 & $<0.20$ \\
\hline \multicolumn{13}{|c|}{$\mathrm{pH}$ value } \\
\hline $\mathrm{D}$ & 7.36 & 7.32 & 7.35 & 7.36 & 7.36 & 7.42 & 7.52 & 7.50 & 7.52 & 7.47 & 7.36 & 7.37 \\
\hline M & 7.30 & 7.23 & 7.32 & 7.41 & 7.33 & 7.40 & 7.42 & 7.47 & 7.37 & 7.45 & 7.38 & 7.36 \\
\hline $\mathrm{K}$ & 7.40 & 7.34 & 7.35 & 7.40 & 7.46 & 7.40 & 7.40 & 7.45 & 7.29 & 7.36 & 7.51 & 7.28 \\
\hline $\mathrm{Lj}$ & 7.40 & 7.45 & 7.40 & 7.39 & 7.45 & 7.46 & 7.55 & 7.56 & 7.52 & 7.48 & 7.40 & 7.49 \\
\hline V & 7.40 & 7.31 & 7.26 & 7.39 & 7.35 & 7.48 & 7.39 & 7.39 & 7.39 & 7.40 & 7.40 & 7.43 \\
\hline \multicolumn{13}{|c|}{$\begin{array}{l}\text { Electrical conduc- } \\
\text { tivity }(\mu \mathrm{S} / \mathrm{cm})\end{array}$} \\
\hline $\mathrm{D}$ & 454 & 451 & 467 & 450 & 458 & 460 & 454 & 450 & 454 & 460 & 460 & 474 \\
\hline$M$ & 465 & 467 & 469 & 450 & 465 & 460 & 463 & 460 & 474 & 466 & 460 & 477 \\
\hline K & 497 & 494 & 487 & 480 & 483 & 492 & 510 & 503 & 511 & 503 & 498 & 501 \\
\hline $\mathrm{Lj}$ & 436 & 435 & 450 & 456 & 454 & 456 & 448 & 444 & 448 & 455 & 459 & 451 \\
\hline V & 465 & 478 & 466 & 457 & 460 & 457 & 487 & 463 & 468 & 493 & 464 & 462 \\
\hline \multicolumn{13}{|c|}{$\mathrm{NO}^{3-}(\mathrm{mg} / \mathrm{L})$} \\
\hline $\mathrm{D}$ & 3.5 & 2.7 & 1.9 & 2.7 & 2.3 & 2.3 & 2.5 & 2.6 & 3.0 & 3.1 & 3.0 & 2.4 \\
\hline M & 4.1 & 3.2 & 3.4 & 3.7 & 3.2 & 2.8 & 3.1 & 3.4 & 3.4 & 3.3 & 3.6 & 2.4 \\
\hline $\mathrm{K}$ & 3.7 & 3.5 & 2.5 & 2.7 & 2.6 & 3.2 & 2.8 & 3.3 & 3.5 & 3.6 & 3.7 & 3.3 \\
\hline $\mathrm{Lj}$ & 3.2 & 2.7 & 3.1 & 2.7 & 3.5 & 2.6 & 2.7 & 2.9 & 3.1 & 3.0 & 2.9 & 2.9 \\
\hline V & 3.5 & 3.5 & 2.9 & 3.0 & 2.5 & 2.8 & 3.1 & 3.4 & 3.2 & 3.8 & 3.9 & 3.5 \\
\hline \multicolumn{13}{|c|}{$\mathrm{Ca}(\mathrm{mg} / \mathrm{L})$} \\
\hline D & 89.3 & 87.2 & 88.2 & 88.4 & 89.23 & 89.5 & 90.1 & 95.5 & 88.3 & 97.1 & 94.2 & 99.9 \\
\hline M & 83.5 & 87.7 & 85.2 & 86.5 & 88.1 & 92.4 & 84.6 & 82.6 & 83.4 & 90.5 & 97.3 & 103.1 \\
\hline $\mathrm{K}$ & 101.7 & 99.8 & 102.9 & 98.6 & 96.6 & 90.2 & 93.4 & 97.7 & 97.4 & 99.2 & 92.5 & 103.9 \\
\hline $\mathrm{Lj}$ & 86.2 & 88.7 & 89.6 & 82.2 & 90.2 & 81.8 & 83.9 & 84.1 & 85.2 & 88.2 & 90.2 & 90.3 \\
\hline V & 85.7 & 83.6 & 82.8 & 84.4 & 86.1 & 90.9 & 89.2 & 87.6 & 89.9 & 84.3 & 89.5 & 88.7 \\
\hline \multicolumn{13}{|c|}{$\mathrm{Mg}(\mathrm{mg} / \mathrm{L})$} \\
\hline $\mathrm{D}$ & 9.2 & 8.7 & 10.3 & 6.8 & 8.7 & 8.6 & 9.2 & 10.4 & 10.7 & 7.6 & 8.5 & 5.3 \\
\hline M & 12.1 & 10.4 & 11.5 & 8.2 & 13.9 & 8.1 & 11.9 & 13.0 & 13.3 & 8.9 & 6.4 & 2.2 \\
\hline $\mathrm{K}$ & 9.4 & 7.9 & 7.6 & 7.8 & 8.7 & 10.4 & 9.1 & 10.2 & 9.2 & 9.3 & 8.6 & 7.8 \\
\hline $\mathrm{Lj}$ & 7.3 & 9.1 & 9.6 & 5.4 & 8.4 & 10.9 & 9.3 & 7.9 & 7.5 & 7.4 & 9.2 & 6.5 \\
\hline V & 10.7 & 7.8 & 14.1 & 8.6 & 8.4 & 7.2 & 10.8 & 12.8 & 12.9 & 9.2 & 7.9 & 6.4 \\
\hline \multicolumn{13}{|c|}{$\mathrm{SO}^{2-}(\mathrm{mg} / \mathrm{L})$} \\
\hline $\mathrm{D}$ & 14.8 & 12.4 & 14.3 & 9.3 & 8.1 & 8.1 & 8.8 & 16.4 & 6.2 & 10.2 & 13.5 & 7.8 \\
\hline M & 13.3 & 11.9 & 13.2 & 7.6 & 10.5 & 8.1 & 7.8 & 14.5 & 7.1 & 9.5 & 8.7 & 8.0 \\
\hline $\mathrm{K}$ & 12.6 & 8.8 & 9.4 & 12.1 & 6.9 & 13.0 & 7.4 & 13.2 & 6.8 & 11.6 & 9.6 & 8.8 \\
\hline $\mathrm{Lj}$ & 10.6 & 7.9 & 10.6 & 8.4 & 9.7 & 11.2 & 9.1 & 7.9 & 7.7 & 9.0 & 10.6 & 8.9 \\
\hline V & 13.5 & 9.2 & 16.8 & 8.7 & 10.6 & 15.8 & 8.9 & 9.3 & 11.8 & 10.2 & 11.4 & 7.8 \\
\hline
\end{tabular}


Studies suggest that in concentrations between 1000 and $1200 \mathrm{mg} / \mathrm{L}$ sulfates have a laxative effect but without diarrhea, dehydration and weight loss [47]. US EPA [38] categorized sulfates into the secondary group of contaminants and placed a secondary MCL of $250 \mathrm{mg} / \mathrm{L}$. According to the EU Directive [7] under the condition that water is not aggressive and in accordance with the Ordinance on the hygienic adequacy of drinking water in the Republic of Serbia [35], the maximum allowed content for sulfates is $250 \mathrm{mg} / \mathrm{L}$. Sulfate presence in drinking water may affect taste. The lowest threshold for the sulfate taste perception is about $250 \mathrm{mg} / \mathrm{L}$ (sodium salt). Also, sulfates may contribute to corrosion in distribution systems [47]. The sulfate concentrations with the greatest measured value of $16.8 \mathrm{mg} / \mathrm{L}$ in all water samples from the springs and the reservoir meet the recommended values and the maximum allowed concentration. In Serbia, Banat, groundwater with high arsenic content up to $217 \mu \mathrm{g} / \mathrm{L}$ has a low sulfate concentration ranging from 3 to $90 \mathrm{mg} / \mathrm{L}$ [22].

The content of magnesium and calcium in ground water of Serbia varies in a very wide range depending on the observed area and is a consequence of the highly complex geological structure of Serbia [17]. Due to a greater diffusion in nature, calcium concentration in natural waters is higher than magnesium concentration. Together with magnesium, most commonly in the form of carbonates and bicarbonates calcium makes water hard. Magnesium in groundwater goes up to $50 \mathrm{mg} / \mathrm{L}$ and rarely exceeds $100 \mathrm{mg} / \mathrm{L}$ wherefore the main component of hardness is calcium [46]. Hard water leads to the sedimentation of limescale in water pipes, taps, and heaters which decreases their working efficiency. On the other hand, in the last five decades, ecological, epidemiological and analytical (anamnestic) data have been accumulated on the protective effect of high values of hardness and $\mathrm{Ca}$ and $\mathrm{Mg}$ from drinking water on morbidity and mortality from cardiovascular disease [11, 28, 31]. Even though many studies shave favored $\mathrm{Mg}$ as the main protective element of hard water for IHD $[6,26]$, Rylander in his most recent study has concluded that $\mathrm{Mg}$ and $\mathrm{Ca}$ have to be taken into account together, as the analysis of many epidemiological and experimental studies has shown that the risk of death from cardiovascular disease was associated with both the content of $\mathrm{Mg}$ and the content of $\mathrm{Ca}$ [29]. It is proven that soft water substantially reduces the content of various essential elements (including $\mathrm{Ca}$ and $\mathrm{Mg}$ ) in food if used for cooking vegetables, meat, and grain. Reductions go up to $60 \%$ for $\mathrm{Mg}$ and Ca or even more for some microelements (Ex. Cu 66\%, Mn 70\%, Co 86\%). As opposed to that if hard water is used in cooking there is a lesser reduction of elements (Haring and Van Dleft 1980). WHO [44] in the drinking water quality guide estimated calcium and magnesium from the perspective of water hardness. But, it did not set any minimum or maximum recommended values. The EU Directive [7] and US EPA [38] did not standardize calcium and magnesium either. The Ordinance on the hygienic adequacy of drinking water in the Republic of Serbia [35] set the maximum allowed content of calcium to $200 \mathrm{mg} / \mathrm{L}$ and magnesium to $50 \mathrm{mg} / \mathrm{L}$. The calcium concentration, with the highest measured value of $103.9 \mathrm{mg} / \mathrm{L}$ and the magnesium concentration, with the greatest measured value of $14.1 \mathrm{mg} / \mathrm{L}$, in all water samples from the springs and the reservoir meets the recommended values and the maximum allowed concentration (Table 1).

The iron concentrations in all water samples from the springs and the reservoir are below the method's detection threshold $(<0.01 \mathrm{mg} / \mathrm{L})$ and thus meet the recommended values and the maximum allowed concentration. Iron does not pose health risks at concentrations which occur in natural water which is why WHO [44] didn't recommend guidelines. However, at concentrations higher than $0.3 \mathrm{mg} / \mathrm{L}$ water may acquire turbidity and color and as a result of iron-oxidizing bacteria, pipes may be lined with mucous layers. The results of some research discover that occluded water in the scales of the pipes has an acidic environment and high concentration of iron, manganese, chloride, sulfate and nitrate, which aggravates many pipeline leakage accidents [37]. US EPA [38] categorized iron as a secondary contaminant and set a secondary $\mathrm{MCL}$ of $0.3 \mathrm{mg} / \mathrm{L}$. The reason for that is its influence on the organoleptic water characteristics: the color of rust in water, metal taste, reddish or orange coloration. Iron also promotes the growth of iron-oxidizing bacteria. These bacteria obtain their energy precisely from the oxidation process of $\mathrm{Fe}^{2+}$ into $\mathrm{Fe}^{3+}$ ions which leads to the formation of a slimy layer in pipes. This problem appears with iron concentrations above $0.3 \mathrm{mg} / \mathrm{L}$. The EU Directive [7] set the maximum allowed content for iron in water to $0.2 \mathrm{mg} / \mathrm{L}$. In accordance with the Ordinance on the hygienic adequacy of drinking water in the Republic of Serbia [35] the maximum allowed concentration of iron in water is $0.3 \mathrm{mg} / \mathrm{L}$. In northern Serbia, in Subotica, the iron concentration in groundwater samples varies from 0.04 to $0.96 \mathrm{mg} / \mathrm{L}$ [22].

The manganese concentrations in all water samples from the springs and the reservoir are below the method's detection threshold $(<0.025 \mathrm{mg} / \mathrm{L})$ thereby meeting the recommended values and the maximum allowed content. Manganese belongs to the elements whose presence in groundwater is considered natural [44]. Certainly, it can occur there as a result of anthropogenic actions. The behavior of manganese in water is similar to that of iron. Manganese also promotes the development of manganese-oxidizing bacteria. These bacteria obtain energy for growth precisely from the oxidation process of $\mathrm{Mn}^{2+}$ into $\mathrm{Mn}^{3+}$, which leads to the formation of a slimy layer in pipes. This problem occurs at manganese concentrations 
above $0.1 \mathrm{mg} / \mathrm{L}$ [44]. These bacteria are not detrimental to health; however, they may cause clogging in the water system [8]. At manganese concentrations above $0.1 \mathrm{mg} / \mathrm{L}$ water taste becomes bad and stains appear in water pipes and on laundry [44]. WHO [44] did not set guidelines for manganese as the concentrations at which it appears in drinking water do not affect health. However, at concentrations higher than $0.1 \mathrm{mg} / \mathrm{L}$, it causes an unpleasant taste and it colors pipes and laundry. Like iron, it may lead to the accumulation of sediment in the distribution system. Concentrations below $0.1 \mathrm{mg} / \mathrm{L}$ are acceptable for consumers. US EPA [38] categorized manganese as a secondary contaminant and set a secondary $\mathrm{MCL}$ of $0.05 \mathrm{mg} / \mathrm{L}$. According to the EU Directive [7] and the Ordinance on the hygienic adequacy of drinking water in the Republic of Serbia [35] the maximum allowed content for manganese is $0.05 \mathrm{mg} / \mathrm{L}$. In the groundwater of the Pannonian Basin (eastern Hungary and western Romania), manganese concentrations vary from $<0.001$ to $0.336 \mathrm{mg} / \mathrm{L}$ [27].

The $\mathrm{Cr}^{3+}$ and $\mathrm{Cr}^{6+}$ concentrations in all water samples from the springs and the reservoir are below the method's detection threshold $(<0.01 \mathrm{mg} / \mathrm{L})$ and therefore meet the recommended values and the maximum allowed concentration. The distribution of compounds containing $\mathrm{Cr}^{3+}$ and $\mathrm{Cr}^{6+}$ depends on the reduction potential, $\mathrm{pH}$ value, oxidizing and reducing compounds presence, kinetics of reduction reactions, formation of $\mathrm{Cr}^{3+}$ complexes or insoluble $\mathrm{Cr}^{3+}$ salts and the total chromium concentration. When chromium concentration is low, $\mathrm{Cr}^{3+}$ is present as a monovalent $\mathrm{HCrO}_{4}{ }^{-}$below the $\mathrm{pH}$ value of 6.5 and divalent $\mathrm{CrO}_{4}{ }^{2-}$ at the $\mathrm{pH}$ value between 6.5 and 10 [24]. In water without oxygen or with a very low concentration of it, $\mathrm{Cr}^{3+}$ is a dominant particle which occurs in the cationic $\left(\mathrm{Cr}^{3+}\right.$, $\mathrm{CrOH}^{2+}$ or $\left.\mathrm{Cr}(\mathrm{OH})\right)$ or the neutral $\left(\mathrm{Cr}(\mathrm{OH})_{3}\right)$ form depending on the $\mathrm{pH}$ value. $\mathrm{Cr}^{3+}$ is insoluble $(<20 \mu \mathrm{g} / \mathrm{L})$ within the $\mathrm{pH}$ range of 7 to 10 , with the minimum solubility at the $\mathrm{pH}$ value of $8(1 \mu \mathrm{g} / \mathrm{L})$ [24]. In natural minerals, chromium mostly appears in the form of $\mathrm{Cr}^{3+}$. Since the effect on health depends on the state of chromium's oxidation, WHO [44] considers that separate guidelines for $\mathrm{Cr}^{3+}$ and $\mathrm{Cr}^{6+}$ should be set. However, the current analytic methods and the variable chromium speciation in water favor guidelines for total chromium. WHO [44] set a temporary guideline for total chromium of $50 \mu \mathrm{g} / \mathrm{L}$. Because it can cause allergic dermatitis US EPA [38] set MCL and MCLG (Maximum Contaminant Level Goal) for total chromium at $100 \mu \mathrm{g} / \mathrm{L}$. According to the EU Directive [7] and the Ordinance on the hygienic adequacy of drinking water in the Republic of Serbia [35], the total chromium content in drinking water must not exceed $50 \mu \mathrm{g} / \mathrm{L}$. The results of Croatia's studies have shown that contaminated groundwater ( $\mathrm{Fe}, \mathrm{Pb}, \mathrm{Ni}$ and $\mathrm{Cr}$ ) becomes a large hygienic and toxicological problem, since it considerably impedes groundwater utilization [9]. Even though, all of these contaminants have not yet reached toxic levels, they still represent long-term risk for health of the population [9].

Aluminum presence points to the assumption that the water system is supplied from artesian wells located in the industrial zone. Aluminum poses a risk to human health, primarily in mines but also factory workers may have lung problems due to aluminum dust. Elevated aluminum concentrations may lead to significant health problems, primarily nervous system problems, dementia, memory loss, and diarrhea. It is suspected that drinking water containing fluoride and aluminum results in negative health effects especially on brain, liver, and kidney [41]. But, it was demonstrated that the treated drinking water containing $\mathrm{F}$ and $\mathrm{Al}$ with par with $\mathrm{WHO}$ or moderately above the WHO levels or AIFx in low level $(0.07-15 \mathrm{mg} / \mathrm{L})$ does not lead to CKD in mice [41]. In kidney patients, it may cause problems when it gets inside the organism through kidney dialysis. There is a suspicion that it might have an effect on the appearance of Alzheimer's disease (WHO, Guidelines for drinking water quality [43]). According to WHO [44] the limit for aluminum in drinking water is $200.0 \mu \mathrm{g} / \mathrm{L}$. According to the Ordinance on the hygienic adequacy of drinking water in the Republic of Serbia [35], the maximum allowed concentration of aluminum is also $200.0 \mu \mathrm{g} / \mathrm{L}$. The aluminum content in all water samples from the springs and the reservoir is below the method's detection threshold $(<0.020 \mathrm{mg} / \mathrm{L})$ thus meeting the recommended values and the maximum allowed content.

\subsection{Microbiological water quality monitoring}

The numbers of culturable organisms (TCV) in natural water samples from the springs are given in Table 2.

Even though this parameter is not an indicator of fecal contamination in water, it is useful for the estimation of general bacteria content in water. From the results we can observe that the measured values of these bacteria went up to $212 \mathrm{cfu} / \mathrm{mL}$ (one sample from Krupac Spring) and that only one more sample from that spring had a value above the maximum allowed concentration $(107 \mathrm{cfu} / \mathrm{mL})$ according to the ordinance (100 cfu) for natural water from enclosed springs. By comparing the results with the values from the physicochemical analysis, it can be inferred that in the periods of elevated turbidity at this spring (5.4-5.7 NTU), the bacterial load is the greatest. This is understandable considering that bacteria are suspended particles which, among other things, may affect the increased turbidity values. All the other values of this parameter were far below the maximum allowed concentration, ranging from 1-11 cfu/mL (Divljana, July).

Total coliform bacteria (TC) which are not of fecal origin may exist in natural water and their presence can be 
Table 2 An annual basis representation of the number (n) of culturable organisms (TCV), total coliform bacteria (TC), fecal coliform bacteria (FC), intestinal enterococci (SF), sulfite-reducing clostridia
(SSA), Pseudomonas aeruginosa (PA), and Proteus strain (Pv) in the raw water from the springs Divljana (D), Mokra (M), Krupac (K) Ljuberadja (Lj) and and the Vinik (V) reservoir

\begin{tabular}{|c|c|c|c|c|c|c|c|c|c|c|c|c|}
\hline Month & January & February & March & April & May & June & July & August & September & October & November & December \\
\hline \multicolumn{13}{|c|}{$\mathrm{TCV}$ at $37^{\circ} \mathrm{C}, \mathrm{cfu} / 1 \mathrm{~mL}$} \\
\hline $\mathrm{D}$ & $<1$ & 1 & $<1$ & $<1$ & $<1$ & $<1$ & 11 & $<1$ & $<1$ & $<1$ & $<1$ & $<1$ \\
\hline M & 1 & 1 & $<1$ & $<1$ & $<1$ & $<1$ & $<1$ & $<1$ & $<1$ & $<1$ & $<1$ & 5 \\
\hline $\mathrm{K}$ & $<1$ & 5 & 212 & $<1$ & 4 & 1 & $<1$ & 47 & 1 & $<1$ & 11 & 107 \\
\hline $\mathrm{Lj}$ & $<1$ & 2 & $<1$ & $<1$ & $<1$ & $<1$ & $<1$ & $<1$ & $<1$ & $<1$ & $<1$ & $<1$ \\
\hline V & $<1$ & $<1$ & $<1$ & $<1$ & $<1$ & $<1$ & $<1$ & $<1$ & $<1$ & $<1$ & $<1$ & $<1$ \\
\hline \multicolumn{13}{|c|}{$\mathrm{TC} \mathrm{n} / 100 \mathrm{~mL}$} \\
\hline $\mathrm{D}$ & 1 & $\Theta$ & $\Theta$ & $\Theta$ & 1 & 5 & 13 & 2 & $\Theta$ & $\Theta$ & 24 & 1 \\
\hline M & 1 & 17 & $\Theta$ & 2 & $\Theta$ & 7 & 24 & $\Theta$ & 3 & 10 & 8 & $\Theta$ \\
\hline $\mathrm{K}$ & 24 & 1 & 31 & 1 & 8 & 54 & 24 & 24 & $\Theta$ & 1 & 92 & $>161$ \\
\hline $\mathrm{Lj}$ & 1 & $\Theta$ & $>161$ & $\Theta$ & $\Theta$ & 1 & $\Theta$ & 1 & $\Theta$ & $\Theta$ & $\Theta$ & $\Theta$ \\
\hline V & $\Theta$ & $\Theta$ & $\Theta$ & $\Theta$ & $\Theta$ & $\Theta$ & $\Theta$ & $\Theta$ & $\Theta$ & $\Theta$ & $\Theta$ & $\Theta$ \\
\hline \multicolumn{13}{|c|}{$\mathrm{FC} \mathrm{n} / 100 \mathrm{~mL}$} \\
\hline $\mathrm{D}$ & 1 & $\Theta$ & $\Theta$ & $\Theta$ & 1 & 5 & 3 & $\Theta$ & $\Theta$ & $\Theta$ & 24 & 1 \\
\hline M & $\Theta$ & $\Theta$ & $\Theta$ & 1 & $\Theta$ & 7 & 24 & $\Theta$ & $\Theta$ & 10 & 3 & $\Theta$ \\
\hline $\mathrm{K}$ & 24 & 1 & 31 & 1 & 8 & 24 & 24 & 24 & $\Theta$ & 1 & 17 & $>161$ \\
\hline $\mathrm{Lj}$ & $\Theta$ & $\Theta$ & $\Theta$ & $\Theta$ & $\Theta$ & 1 & $\Theta$ & 1 & $\Theta$ & $\Theta$ & $\Theta$ & $\Theta$ \\
\hline V & $\Theta$ & $\Theta$ & $\Theta$ & $\Theta$ & $\Theta$ & $\Theta$ & $\Theta$ & $\Theta$ & $\Theta$ & $\Theta$ & $\Theta$ & $\Theta$ \\
\hline \multicolumn{13}{|c|}{$\mathrm{SF} \mathrm{n} / 100 \mathrm{~mL}$} \\
\hline $\mathrm{D}$ & $\Theta$ & $\Theta$ & $\Theta$ & $\Theta$ & $\Theta$ & $\Theta$ & $\Theta$ & 1 & 1 & $\Theta$ & 1 & 1 \\
\hline M & $\Theta$ & $\Theta$ & $\Theta$ & $\Theta$ & $\Theta$ & $\Theta$ & 1 & $\Theta$ & $\Theta$ & 4 & 1 & 3 \\
\hline $\mathrm{K}$ & 1 & $\Theta$ & 13 & $\Theta$ & 3 & 24 & 24 & $\Theta$ & $\Theta$ & $\Theta$ & 92 & $>161$ \\
\hline $\mathrm{Lj}$ & $\Theta$ & $\Theta$ & $\Theta$ & $\Theta$ & $\Theta$ & $\Theta$ & $\Theta$ & $\Theta$ & $\Theta$ & $\Theta$ & $\Theta$ & $\Theta$ \\
\hline V & $\Theta$ & $\Theta$ & $\Theta$ & $\Theta$ & $\Theta$ & $\Theta$ & $\Theta$ & $\Theta$ & $\Theta$ & $\Theta$ & $\Theta$ & $\Theta$ \\
\hline \multicolumn{13}{|c|}{$\mathrm{SSA} \mathrm{n} / 100 \mathrm{~mL}$} \\
\hline $\mathrm{D}$ & $\Theta$ & $\Theta$ & $\Theta$ & $\Theta$ & $\Theta$ & $\Theta$ & $\Theta$ & $\Theta$ & $\Theta$ & $\Theta$ & 2 & $\Theta$ \\
\hline M & $\Theta$ & $\Theta$ & $\Theta$ & $\Theta$ & $\Theta$ & $\Theta$ & 1 & $\Theta$ & $\Theta$ & $\Theta$ & $\Theta$ & $\Theta$ \\
\hline K & 2 & 3 & 1 & $\Theta$ & $\Theta$ & $\Theta$ & $\Theta$ & $\Theta$ & $\Theta$ & $\Theta$ & $\Theta$ & 3 \\
\hline $\mathrm{Lj}$ & $\Theta$ & $\Theta$ & 2 & $\Theta$ & $\Theta$ & $\Theta$ & $\Theta$ & 1 & $\Theta$ & $\Theta$ & $\Theta$ & $\Theta$ \\
\hline V & $\Theta$ & $\Theta$ & $\Theta$ & $\Theta$ & $\Theta$ & $\Theta$ & $\Theta$ & $\Theta$ & $\Theta$ & $\Theta$ & $\Theta$ & $\Theta$ \\
\hline \multicolumn{13}{|c|}{$\mathrm{PA} \mathrm{n} / 100 \mathrm{~mL}$} \\
\hline $\mathrm{D}$ & $\Theta$ & $\Theta$ & $\Theta$ & $\Theta$ & $\Theta$ & $\Theta$ & $\Theta$ & $\Theta$ & $\Theta$ & $\Theta$ & $\Theta$ & $\Theta$ \\
\hline M & $\Theta$ & $\Theta$ & $\Theta$ & $\Theta$ & $\Theta$ & $\Theta$ & $\Theta$ & $\Theta$ & $\Theta$ & $\Theta$ & $\Theta$ & $\Theta$ \\
\hline $\mathrm{K}$ & $\Theta$ & $\Theta$ & $\Theta$ & $\Theta$ & $\Theta$ & $\Theta$ & 1 & $\Theta$ & $\Theta$ & $\Theta$ & $\Theta$ & $\Theta$ \\
\hline Lj & $\Theta$ & $\Theta$ & $\Theta$ & $\Theta$ & $\Theta$ & $\Theta$ & $\Theta$ & $\Theta$ & $\Theta$ & $\Theta$ & $\Theta$ & $\Theta$ \\
\hline V & $\Theta$ & $\Theta$ & $\Theta$ & $\Theta$ & $\Theta$ & $\Theta$ & $\Theta$ & $\Theta$ & $\Theta$ & $\Theta$ & $\Theta$ & $\Theta$ \\
\hline \multicolumn{13}{|c|}{ Pv n/100 mL } \\
\hline $\mathrm{D}$ & $\Theta$ & $\Theta$ & $\Theta$ & $\Theta$ & $\Theta$ & $\Theta$ & $\Theta$ & $\Theta$ & $\Theta$ & $\Theta$ & $\Theta$ & $\Theta$ \\
\hline M & $\Theta$ & $\theta$ & $\Theta$ & $\Theta$ & $\Theta$ & $\Theta$ & $\theta$ & $\theta$ & $\Theta$ & $\Theta$ & $\Theta$ & $\Theta$ \\
\hline $\mathrm{K}$ & $\Theta$ & $\Theta$ & $\Theta$ & $\Theta$ & $\Theta$ & $\Theta$ & $\Theta$ & $\Theta$ & $\Theta$ & $\Theta$ & $\Theta$ & $\Theta$ \\
\hline $\mathrm{Lj}$ & $\Theta$ & $\Theta$ & $\Theta$ & $\Theta$ & $\Theta$ & $\Theta$ & $\Theta$ & $\Theta$ & $\Theta$ & $\Theta$ & $\Theta$ & $\Theta$ \\
\hline $\mathrm{V}$ & $\theta$ & $\theta$ & $\theta$ & $\theta$ & $\Theta$ & $\Theta$ & $\Theta$ & $\Theta$ & $\theta$ & $\Theta$ & $\theta$ & $\Theta$ \\
\hline
\end{tabular}

cfu- the number of formed colonies

$\Theta-$ no bacteria 
tolerated to a degree, so the Ordinance on the hygienic adequacy of drinking water [35], allows up to 10 TC bacteria in $100 \mathrm{~mL}$ of natural water samples from enclosed springs. An annual basis representation of these bacteria in our research (Table 2 ) indicates that the values in examined water samples range from 1 to $24 / 100 \mathrm{~mL}$ and that Krupac Spring, in the second half of the year, has values from 54 to $161 / 100 \mathrm{~mL}$. Ljuberadja Spring, which is predominantly without TC bacteria findings, had elevated values of total coliform bacteria in March only in one sample $(>161 / 100 \mathrm{~mL})$. Research in the world has shown that the total coliform bacteria in a high percentage (55.3\%) can be found in tap water samples [21].

A more suitable name for fecal coliform bacteria (FC) is thermostable coliform bacteria and aside from E.coli water samples mostly contain Klebsiella, Enterobacter and Citrobacter. The discovery of these bacteria suggests a recent fecal contamination and an epidemiological hazard from a potential finding of pathogenic microorganisms. Most drinking water sources were found to have coliform counts above the recommended national and international guidelines [2]. Research in Jakarta shows that bouts of diarrhea, reported in one-third of households were closely related to water contaminated with more than $100 \mathrm{fecal}$ coliform bacteria in $100 \mathrm{~mL}$ of water samples [40]. In the USA, up to $14 \%$ of the population depend on private wells as their primary drinking water source and $E$. coli, arsenic and nitrate concentrations exceeded their respective regulatory levels [20].

When it comes to E. coli and other indicators of fecal contamination, primarily intestinal Enterococci (SF), but also Proteus strains (Pv) and Pseudomonas aeruginosa (PA), the Ordinance on the hygienic adequacy of drinking water [35], and the EU Directive [7] do not permit the finding of these bacteria in drinking water (neither natural nor disinfected). Microbiological research results for fecal contamination indicating bacteria are given in Table 2 where it can be observed that the bacteriological load in natural water with FC and SF bacteria is the greatest in summer months as well as at the end of the year, especially when springs are turbid (Krupac Spring). Analyses around the world suggest that routine inspection of drinking water's bacteriological quality for the presence of coliform bacteria is very important in relation to the viral assessment of the presence of enteric viruses, especially hepatitis $A$ in water [16].

Proteus strains, as indicators of fecal contamination and organic matter decomposition, were not isolated in any of the samples from the springs belonging to the LjuberadjaNiš system (Table 2).

Pseudomonas aeruginosa, which are considered to be highly resistant in nature and resistant to disinfectants, was not isolated in the water of this system except one sample from Krupac Spring (July) (Table 2). In contrast to public believe, bottled waters are not free of Pseudomonas aeruginosa, and it is suggested that authorities should provide stricter monitoring and control plan for water resources and plants [18].

Sulfite reducing sporogenic anaerobic bacteria (Clostridia) (SSA) are indicators of old fecal contamination and the Ordinance on the hygienic adequacy of drinking water [35] allows one SSA bacteria in a natural water sample of $100 \mathrm{~mL}$ from an enclosed spring whereas they are not permitted in chlorinated water. In our analysis (Table 2), these bacteria were isolated in a lesser number $(2-3 / 100 \mathrm{~mL})$ in several samples from Krupac Spring while the rest of the springs (Divljana, Mokra, and Ljuberadja) are commonly without SSA bacteria or may have sporadic occurrences in small quantities $(1-2 / 100 \mathrm{~mL})$.

The microbiological testing of chlorinated water quality from the Vinik reservoir shows (Table 2) that none of the samples contain the mentioned bacteria. This confirms the hygienic adequacy of the water distributed to consumers. It is necessary to emphasize that besides chlorination proper maintenance of the distributive network is very significant in terms of preserving drinking water safety. Research from around the world suggests that bacteriological contamination in water may deteriorate when sanitary protection zones are poorly managed, when water is treated inadequately and when the distribution system is not maintained [5, 15]. A high degree of microbiological contamination in drinking water for households certainly is a hazard for consumers' health [1], which is definitely not the case with the drinking water from the LjuberadjaNiš system considering that the microbiological examination of water quality shows that consumers receive $100 \%$ microbiologically safe tap water.

\section{Conclusions}

Quality monitoring has shown that groundwater is the most reliable source of drinking water.

Except occasional increases in turbidity only in natural water samples, physical, and chemical parameters in tested water system Ljuberadja-Niš are below the values of the maximum allowed concentration prescribed by national and international authorities.

Despite the fact that microbiological analysis detects sporadic microbiological contamination in natural water, primarily with coliform (total and fecal) bacteria, after gas chlorine disinfection the health and hygienic adequacy is achieved. By comparing the results with the values from the physicochemical analysis it can be inferred that in the periods of elevated turbidity at this spring the bacterial 
load is the greatest (primarily the increased number of culturable organisms).

The microbiological testing of chlorinated water quality from the Vinik reservoir shows that none of the samples contain the tested bacteria.

Monitoring has confirmed the hygienic and health adequacy of the water distributed to consumers.

In order to maintain the health safety of drinking water, it is necessary to continue quality monitoring by examining the physical, chemical, and microbiological parameters at the same time.

\section{Compliance with ethical standards}

Conflict of interest The author(s) declare that they have no competing interests.

\section{References}

1. Agard L, Alexander C, Green S, Jackson M, Patel S, Adesiyun A (2002) Microbial quality of water supply to an urban community in Trinidad. J Food Prot 65(8):1297-1303

2. Agensi A, Tibyangye J, Tamale A, Agwu E, Amongi C (2019) Contamination potentials of household water handling and storage practices in Kirundo Subcounty, Kisoro District. Uganda J Environ Public Health 2019:7932193

3. Ako AA, Shimada J, Hosono T, Kagabu M, Akoachere RA, Nkeng GE, Takem GE, Fouepe A (2012) Spring water quality and usability in the Mount Cameroon area revealed by hydrogeochemistry. Environ Geochem Health 34(5):615-639

4. Annual Report of Public Waterworks VOD-2V (2004) Republic Institute for Statistics.

5. Chemuliti JK, Gathura PB, Kyule MM, Njeruh FM (2002) Bacteriological qualities of indoor and out-door drinking water in Kibera sub-location of Nairobi. Kenya East Afr Med J 79(5):271-273

6. Del Gobbo LC, Imamura F, Wu JHY et al (2013) Circulating and dietary magnesium and risk of cardiovascular disease: a systematic review and meta-analysis of prospective studies. Am J Clin Nutr 98:160-173

7. EU Council Directive $98 / 83 / E C$ (1998) On the quality of water intended for human consumption. Drinking Water Directive (DWD), Official Journal L 330-332.

8. Gerke TL, Little BJ, Barry Maynard J (2016) Manganese deposition in drinking water distribution systems. Sci Total Environ 541:184-193

9. Gvozdić V, Cacić LJ, Brana J, Puntarić D, Vidosavljević D (2012) Chemometric analysis of groundwater quality data around municipal landfill and paper factory and their potential influence on population's health. Med Glas Ljek komore Zenickodoboj kantona 9(1):91-96

10. Haring BSA, Van Delft W (1981) Changes in the mineral composition of food as a result of cooking in "hard" and "soft" waters. Arch Environ Health 36(1):33-35

11. Hoque MA, Butler AP (2016) Medical hydrogeology of Asian deltas: status of groundwater toxicants and nutrients, and implications for human health. Int J Environ Res Public Health 13(1):81

12. Huang J, Chow CWK, Kuntke P et al (2019) The development and evaluation of a microstill with conductance detection for low level ammonia monitoring in chloraminated water. Talanta 200(1):256-262

13. Hudak PF (2012) Nitrate and chloride concentrations in groundwater beneath a portion of the trinity group outcrop zone. Texas Int J Environ Res 6(3):663-668

14. Irda Sari SY, Sunjaya DK, Shimizu-Furusawa H, Watanabe C, Raksanagara AS (2018) Water sources quality in Urban Slum settlement along the contaminated river Basin in Indonesia: application of quantitative microbial risk assessment. J Environ Public Health 18:7

15. Komarulzman A, Smits J, De Jong E (2017) Clean water, sanitation and diarrhoea in Indonesia: effects of household and community factors. Glob Public Health 12(9):1141-1155

16. Luksamijarulkul P, Pumsuwan V, Pungchitton S (1994) Microbiological quality of drinking water and using water of a Chao Phya River community, Bangkok. Southeast Asian J Trop Med Public Health 25(4):633-637

17. Milosavljević J, Andrijasević J, Todorović M (2013) Distribution of magnesium in groundwater of Serbia. Geol Ann Balkan Penins 74:83-90

18. Mohammadi Kouchesfahani M, Alimohammadi M et al (2015) Pseudomonas aeruginosa and Heterotrophic Bacteria count in bottled waters in Iran. Iran J Public Health 44(11):1514-1519

19. Mohammed H, Hameed IA, Seidu R (2018) Comparative predictive modelling of the occurrence of faecal indicator bacteria in a drinking water source in Norway. Sci Total Environ 1(628-629):1178-1190

20. Ornelas Van Horne Y, Parks J, Trant T et al (2019) Seasonal variation of water quality in unregulated domestic wells. Int J Environ Res Public Health 16(9):E1569

21. Pant ND, Poundyal N, Bhattacharya SK (2016) Bacteriological quality of bottled drinking water versus municipal tap water in Dharan municipality. Nepal J Health Popul Nutr 35(1):17

22. Papić $P$, Ćuk M, Todorović M, Stojković J, Hajdin B, Atanacković N, Polomčić D (2012) Arsenic in tap water of Serbia's South Pannonian basin and arsenic risk assessment. Pol J Environ Stud 21(6):1783-1790

23. Polomčić D, Hajrudin B, Ćuk M, Papić P, Stevanović Z (2014) Groundwater resources for drinking water supply in Serbian's southeast Pannonian basin. Carpath Earth Environ 9(3):97-108

24. Rai D, Saas BM, Moore DA (1987) Chromium (III) hydrolysis constants and solubility of chromium (III) hydroxide. Inorg Chem 26(3):345-349

25. Reimann C, Banks D (2004) Setting action levels for drinking water: are we protecting our health or our economy (or our backs!)? Sci Total Environ 332:13-21

26. Rosanoff A (2013) The high heart health value of drinkingwater magnesium. Med Hypotheses 81(6):1063-1065

27. Rowland HAL, Omoregie EO, Millot R et al (2011) Geochemistry and arsenic behaviour in groundwater resources of the Pannonian Basin (Hungary and Romania). Appl Geochem 26(1):1-17

28. Rubenowizz-Lundin E, Kevin MH (2013) Water hardness and health effects. Essentials of medical geology. Springer, New York 337-350.

29. Rylander R (2014) Magnesium in drinking water: a case for prevention? J Water Health 12(1):34-40

30. Schullehner J, Stayner L, Hansen B (2017) Nitrate, nitrite, and ammonium variability in drinking water distribution systems. Int J Environ Res Public Health 14(3):276

31. Sengupta $P$ (2013) Potential health impacts of hard water. Int J Prev Med 4(8):866-875

32. Sokolova E, Lindström G, Pers C, Strömqvist J, Lewerin SS, Wahlström H, Sörén SK, K, (2018) Water quality modelling: microbial risks associated with manure on pasture and arable land. J Water Health 16(4):549-561 
33. Standard methods for testing hygienic correctness "Drinking water": Federal Institute for Health Protection (1990) NIP Economic review. City of Belgrade.

34. Stets EG, Lee CJ, Lytle DA, Schock MR (2018) Increasing chloride in rivers of the conterminous US and linkages to potential corrosivity and lead action level exceedances in drinking water. Sci Total Environ 613-614(1):1498-1509

35. The Ordinance on the hygienic adequacy of drinking water in the Republic of Serbia, Official Gazette SRJ no 42/1998; 44/1999; 28/2019.

36. Tomperi J, Juuso E, Eteläniemi M, Leiviskä K (2014) Drinking water quality monitoring using trend analysis. J Water Health 12(2):230-241

37. Tong $\mathrm{H}$, Zhao $\mathrm{P}$, Zhang $\mathrm{H}$ et al (2015) Identification and characterization of steady and occluded water in drinking water distribution systems. Chemosphere 119:1141-1147

38. U.S. EPA (2012) Edition of the drinking water standards and health advisories, EPA 822-S-12-001. Office of Water, Washington, DC

39. Veljković N, Jovičić M (2007) Indicators of sustainable use of underground waters of Serbia. Water Sanitary Technology 37(6):27-37

40. Vollaard AM, Ali S, Smet J, Van Asten H, Widjaja S, Visser LG, Surjadi C, Van Dissel JT (2005) A survey of the supply and bacteriologic quality of drinking water and sanitation in Jakarta, Indonesia. Southeast Asian J Trop Med Public Health 36(6):1552-1561
41. Wasana HM, Perera GD, De Gunawardena PS, Bandara J (2015) The impact of aluminum, fluoride, and aluminum-fluoride complexes in drinking water on chronic kidney disease. Environ Sci Pollut Res Int 22(14):11001-11009

42. WHO (2003) Coastal and fresh waters, Guidelines for safe recreational water environments, 1, Geneva.

43. WHO (2008) Guidelines for drinking water quality, 3rd ed. Incorporating the First and Second Addenda 1, Recommendations, Geneva.

44. WHO (2011) Guidelines for drinking-water quality, 4th edn. World Health Organization, Geneva

45. WHO (2017) Guidelines for drinking-water quality, 4th ed., Incorporating the First Addendum Geneva.

46. WHO (2011b) Hardness in drinking-water, background document for development of WHO. Guidelines for Drinking-water Quality Geneva.

47. WHO (2004b) Sulphate in Drinking-water, background document for preparation of WHO. Guidelines for Drinking-water Quality Geneva.

Publisher's Note Springer Nature remains neutral with regard to jurisdictional claims in published maps and institutional affiliations. 